defects. To compensate for these losses, 17 sturgeon-production units have been built, seven on the lower Volga. Most release 3-gram fingerlings about 30 days after hatching, but probably in quantities too small to compensate for the vast numbers that die near the thousands of intakes of irrigation water. Only two Iranian units, together releasing $4-7 \times 10^{6}$ fingerlings a year, seem to work well. Yet poaching, which increased dramatically after the disintegration of the Soviet Union, is difficult to control, because the riverine states do not agree on the legal status (lake or sea) of the Caspian.

Caviar production has thus gone from bad to worse $(13,300$ tonnes in 1990 to 2,100 tonnes in 1994). A particularly alarming signal came last April, when the Iranian Fisheries Organisation at Nowshahr tried to demonstrate to us how it catches spawners for its hatcheries. To its embarrassment, it caught none. Other stations fared no better.

A decisive blow to the fisheries might come if Mnemiopsis leidyi, a voracious West Atlantic ctenophore, reaches the Caspian. The Lenin Canal between the Don and the Volga allows not only navigation between the Caspian and the Black Sea, but also faunal interchange that has already driven several Caspian endemic species to extinction and caused unwelcome hybridization between Black Sea and Caspian Sea sturgeon. $M$. leidyi reached the Black Sea in the 1980 s, destroying the local pelagic food chain, with the ensuing collapse of fisheries. It could be transported to the Caspian in ballast water: because traffic through the canal is heavy, with no regulation on ballast water, the introduction of $M$. leidyi seems only a matter of time.

What, if any, are the remedies? Like the Californian condor, the sturgeon's only chance of survival may be in captivity. Fortunately, rearing technology is available to keep this Caspian symbol alive in artificial lakes until its original home is ready to welcome it again. Meanwhile, stringent control of poaching and ballast water is important, as well as pollution abatement around the basin. But Turkmenistan is now extending the 1,200-km Karakumski Canal from the Amu-Darya river to the Atrek basin: drainage water contaminated with pesticides sprayed on cottonfields in north and east Turkmenistan may soon enter the Caspian via the Atrek as a new source of pollution. So, ironically, yet more water that would normally flow into the drying Aral will end up in an already overflowing Caspian.

What if the Caspian continues to rise? The phenomenon is not yet understood, although it has been known since antiquity that there is a cyclical pattern of rise and fall. There are at least a dozen possible explanations, in two broad categories: tectonic forcing and climate change, the main influence being that of the North Atlantic oscillation on precipitation in the

\section{Fall and rise of the world's largest lake}

The Caspian Sea is the largest $(384,400$ $\mathrm{km}^{2}$ ) and most voluminous (about $78,700 \mathrm{~km}^{3}$ ) inland body of water on Earth $^{1}$. It lies in an elongated depression between the European and Asian continental plates, its surface well below sea level, with a maximum depth of 980 metres in the south and a shallow northern half averaging only 5.2 metres. The sea extends more than $1,000 \mathrm{~km}$ from north to south, and is bounded by deserts in the north and east, and by grasslands and forests in the west and south. It is an important source of oil and caviar.

The Caspian's low salinity is due to freshwater input. The Volga river contributes up to 82 per cent of the inflow, with the rest supplied by some 130 other rivers, principally the Ural, Kura and Atrek. At $3,530 \mathrm{~km}$ long, the Volga is Europe's largest river, housing half of Russia's population along its length and supplying a quarter of Russia's industrial and agricultural output. Between 1937 and 1981, it was transformed into a chain of reservoirs, designed mainly for the electrification of the Russian countryside and its large-scale industrial and agriculture development.

The Caspian varies in level depending on evaporation and river input. It made the news in the 1960 s when it started receding from its shores (from 126 metres in 1930 to 129 metres in 1977). The decrease was widely held to be due to the filling of the reservoirs along the Volga, but in fact began before these were built. In the 1960 s, Soviet scientists advocated maintaining the lake at a minimum level by diversion of water from northern rivers, thus starting the Soviet Union's first major ecological debate.

The controversy ended abruptly in 1978 when, unexpectedly but rapidly, the Caspian started to rise. Today its level is 126.5 metres and rising. Typically lacking in ecological memory, people moved into the newly emerged lands, developing agriculture (as in the Kura and Volga plains), exploiting oil reserves (as in the Apsheron and Cheleken peninsulas) and establishing townships (as along the Iranian coast, where population density is greatest). All these regions are now flooded.

H. D.
Volga basin ${ }^{2}$. In the final analysis, Caspian people must learn to live with a fluctuating lake level.

Some relief has been provided by the reopening in 1992 of the giant evaporation pan of Kara Bogaz Gol on the east side of the Caspian. The pan and the sea were cut off from one another by a dam in 1980 , built when the last recession was at its worst. The pan may accumulate up to $25 \mathrm{~km}^{3}$ of water, and in three years its refilling has prevented the Caspian from rising a further $35 \mathrm{~cm}$. Thousands of smaller depressions scattered along the east coast could also be artificially flooded - although not before they are first tested for toxic deposits.

But the most perplexing 'solution', proposed by the Committee of Water Resources of Kazakhstan, is the digging of a canal between the Caspian and the Aral. The canal would be about $500 \mathrm{~km}$ long and involve raising the flow of a sizeable river by about 80 metres. The committee claims that only three pumping stations are needed, and the energy required would be supplied by the Gur'evskaia power plant. But it is unclear whether this $350-\mathrm{MW}$ plant is adequate, and inevitably there will be ecological objections. Besides, the Caspian will probably start receding before the capital is raised and the canal dug.

Conservation will require an enormous investment. The littoral governments have been encouraged to work together and submit a funding proposal to the Global Environmental Facility, a US $\$ 2.2$ billion fund, administered jointly by the World Bank and the United Nations Development and Environment Programmes, and aimed at addressing environmental problems of planetary importance. If this is successful, several private donors may also contribute millions of dollars (although the Kazakhcaspishelf consortium, a group of mainly Western oil companies currently carrying out a seismic survey of the northern Caspian in search of more oil, has just withdrawn its support). Nor can the European Union remain indifferent. Indeed, the amount of money ultimately required to save the Caspian may be so large several billion dollars for the clean-up of the Volga valley alone, for instance - that the World Bank, the European Bank for Reconstruction and Development and, of course, the littoral governments themselves may be the only credible investors available.

Henri Dumont is at the Institute of Animal Ecology, State University of Gent, K. I. Ledeganckstraat 35, B-9000 Gent, Belgium.

\footnotetext{
Kosarev, A. N. \& Yablonskaya, E. A. The Caspian Sea (SPB Academic, The Netherlands, 1994)

2. Rodionov, S. N. Global and Regional Climate Interaction: The Caspian Sea Experience (Kluwer, The Netherlands, 1994).
} 